\title{
Lost in Transitions: Childhood and Child Characters in Post-Yugoslav Playwriting ${ }^{* *}$
}

Lost in Transitions: Childhood and Child Characters in Post-Yugoslav Playwriting. The history of Yugoslavia's fall cannot be told without paying attention to transition(s) to democracy and its reflection in art. Playwrights from the emerging countries, including Serbia (Biljana Srbljanović and Milan Marković), Bosnia and Herzegovina (Tanja Šljivar), Montenegro (Maja Todorović) and Kosovo (Jeton Neziraj), use political, economic, and national transitions as a biographical category, comprising various phenomena connected with "interruptions" and "passages" in human life, as well as identified with difficult, extreme, or critical situations. The authors focus on micro-social children's stories, making these young protagonists repositories of anti-knowledge situated on the margins of society. The members of the young generation presented in these dramatic texts go through various transitions marked by new roles and responsibilities. Such descriptions and interpretations of transformations of the surrounding reality can be seen as a new way to illustrate the traumatic predicaments of people living in (post-)transitional societies.

Keywords: childhood, (post-)transitional society, post-Yugoslav playwriting, transition, trauma

Потерянные во время перехода - детство и детские персонажи в пост-югославской драматургии. Трансформация действительности приводит к изменениям ее описания и интерпретации, что отражается в искусстве, в частности в современной пост-югославской драме. В произведениях драматургов из стран с формирующимся рынком - Сербии (Биляна Србьянович и Милан Маркович), Боснии и Герцеговины (Таня Шливар), Черногория (Майя Тодорович) и Косово (Етон Незирай) - переход функционирует как определенная биографическая категория, включающая

* Address: ul. Łączności 11/40, 53-330 Wrocław. E-mail: fuchschen@wp.pl.

** The text is an outcome of the research project No. 2017/24/C/HS2/00436, financed by the National Science Center, Poland. 
в себя различные явления, связанные с «перерывами» и «переходами» в человеческой жизни, отождествляемая со сложными, экстремальными или критическими ситуациями. Некоторые драматурги не остаются равнодушными к изменениям, происходящим в более широком контексте, но они сосредоточены на микросоциальных историях детей. Эти художественные решения представляют молодых протагонистов как хранилище антизнаний, расположенных на периферии общества. Это новая перспектива для выявления травматических переживаний и трудных условий жизни и развития людей в (пост)переходном обществе.

Ключевые слова: детство, (пост)переходное общество, пост-югославская драма, переход, травма

Modern post-Yugoslav playwriting and its stage productions draw limitlessly on the cultural capital of multidimensional transition and its repercussions. Serbian authors, as well as those from neighbouring countries, that is, Bosnia and Herzegovina, Montenegro, and Kosovo ${ }^{1}$, do not remain indifferent to the changes occurring on the wider plane and they focus on a micro-social story, showing intimate problems which result from a given historical moment in concrete spaces. The crucial period in the history of the countries of former Yugoslavia, involving war, crimes, hyperinflation, xenophobia, exile, chauvinism, political ethno-myth, and the domination of ideology, releases, especially in artists, an "organic nausea", the "trauma of apathy" and a spiritual void. ${ }^{2}$ Among the works which employ these elements of biography and reality captured in the time of intense change, the growing number of dramatic texts pivoting on a child protagonist or based on children's collective voice deserve special attention. ${ }^{3}$

A review of selected works should provide answers to the following questions: Was the purpose of the use of a child's perspective to intensify the message and draw attention to the tragic fate of children growing up at the time of the disintegration of Yugoslavia and afterwards? Do the young protagonists personify members of the older generation - disoriented, submissive and restricted in their actions by the decisions remaining in stark contrast to common sentiments? The micro-analyses of the dramatic works are divided according to their authors' nationality. The discussed examples of the dramatic output should be treated as variants of the same phenomenon, because they have one central theme in common: It turns out that all transitions, changes, and transfers impose a state of insecurity and dissonance on

${ }^{1}$ Such an attitude is obviously present in a wider geocultural scope (not only in post-Yugoslav cultures), but the texts discussed here deserve attention due to their specific nature.

${ }^{2}$ R. Vojvodić, "Politički angažman, organska mučnina i sentimentalizam beznađa," [in:] Dramski tekst danas u Bosni i Hercegovini, Hrvatskoj i Srbiji i Crnoj Gori, ed. by S. Anđelković, Novi Sad 2004, p. 185.

${ }^{3}$ Employing child characters and their voices in dramatic works is nothing new. A child character has been introduced by several contemporary authors from former Yugoslavia but they have usually played a marginal role. It is important to underline the fact that in the texts presented here children are the main characters. In addition to drama and theatre, these motifs are also present in films. 
an individual. The process of personalisation, an activity oriented towards an aim and the resulting effort undertaken to adjust the ideals to the current situation are exceptionally complicated. This complexity leads to internal struggle and the sense of being lost, all the more intense for young people.

In very general terms, the notion of transition denotes changes resulting from the dynamics of events affecting human lives, with special emphasis on the interim period between individual stages. This polysemic word is rooted in many disciplines, such as pedagogy, sociology, political science, biology, and information technology. In recent years transition has been an important term that has been frequently used in studies of literature and theatre. In the work of the playwrights from the emerging countries - Serbia, Bosnia and Herzegovina, Montenegro, and Kosovo - transition functions as a biographical category, comprising various phenomena connected with "interruptions" and "passages" in human life, identified with difficult, extreme, or critical situations. ${ }^{4}$ In each case and in each of its manifestations, transition leads to the change in the perception and understanding of the world. This capacious category present in the reflection on human life and development may be defined in a few basic ways. First and foremost, it may be an anticipated and normative passage from one stage to another. It may also be a change caused by a sudden unforeseen event or simply by the absence of anticipated circumstances, which frequently in a very dramatic way - transforms an individual's routine conduct, convictions and role. Transition is also a transformation of one (or many) context(s) in which an individual functions, consisting in a modification of his or her position in a given environment. Apart from these most important distinctions, increasingly common "intercultural transitions" ${ }^{5}$ also deserve interest.

The artists from the countries of former Yugoslavia have devoted a great deal of attention to the traumatic experiences rooted in the critical moments of the last twentyfive years (military actions, ethnic tensions, disintegration of the country, the period of political and economic transition) and their effect on everyday lives of the witnesses to these processes and events. Intensification of changes, their course and outcome difficult or even impossible to predict - trigger the sense of being lost in the transition, both in long-term planning and in small projects concerning one's immediate future. The artistic proposals offered by selected Serbian (Biljana Srbljanović and Milan Marković), Bosnian (Tanja Šljivar), Montenegrin (Maja Todorović) and Kosovan (Jeton Neziraj) playwrights present child characters as a repository of unadulterated counter-knowledge situated on the margins of society. This strategy corresponds with the descriptions of inevitable transformations, often too quick, too intense, unwanted or even traumatic. These concrete cases are predominated by the exposure of exceptionally sensitive individuals - growing up and changing their status, at the same time

${ }^{4}$ V. Drabik-Podgórna, "Tranzycja jako nowa kategoria biograficzna we współczesnym poradnictwie zawodowym," Edukacja Dorostych 2010, no. 1, p. 93.

${ }^{5}$ A. Bańka, Poradnictwo transnacjonalne. Cele i metody międzykulturowego doradztwa karier, Warsaw 2006, p. 92. 
susceptible to the destructive influence of historical perturbances. The children bear enormous social and psychological costs of transition. They are treated as the "others"; deprived of transitional guidance, they experience confusion and uncertainty of their identity. Anthony Giddens remarked that a life is a series of passages and therefore the ability to face them becomes an indispensable skill. ${ }^{6}$ The plays discussed herein, which are largely "about children but not for children", raise the problem of being lost at different levels of transition. They also touch upon the question of exclusion, intolerance, discrimination, violence, and adverse political, social, and economic conditions.

\section{Serbia: Childhood with excess baggage}

Serbian authors Biljana Srbljanović and Milan Marković present the dark side of growing up in a country destroyed by war. They provide examples of how traumatic experiences, adverse conditions of growing up, the absence of acceptable role models and the deprivation of basic psychological needs disturb the development of a young person. The landscape of transitional Serbia emerged primarily as a result of unexpected events which significantly transformed everyday life and disturbed its rhythm. There were also missing situations which in "normal conditions" would be anticipated ${ }^{8}$ and crucial in an appropriate evaluation and disburdening of childhood.

One of the earliest works employing the strategy of focusing on child protagonists is Family Stories ${ }^{9}$ (Porodične priče ${ }^{10}, 1998$ ) by Biljana Srbljanović ${ }^{11}$ (1970, Stockholm). The author explores children's games and "children's fantasy as a magnifying glass to show the harshness of life, which adults are no longer aware of". ${ }^{12}$ Srbljanović resorted to an unorthodox formula: all protagonists are children, whereas the actors are not. Vojin, Milena and Andrija play house on a rubbish tip in one of Belgrade's housing estates, imitating their parents' behaviour and improvising scenes from everyday life consisting of negative social clichés. The closed-off isolated yard functions here as a place of the so-called ritualisation of trauma. Nadežda, who for

${ }^{6}$ A. Giddens, Nowoczesność i tożsamość. "Ja" i społeczeństwo w epoce późnej nowoczesności, trans. by A. Szulżycka, Warsaw 2000, p. 110.

${ }^{7}$ Many authors describe their plays in this way, but there are also those who originally employed the formula of theatre (not only) for a young audience.

${ }^{8}$ N. Schlossberg, E.B. Waters, J. Goodman, Counseling Adults in Transitions - Linking Practice with Theory, New York 1995, p. 27.

9 B. Srbljanović, Family Stories, trans. by V. Janković, "Scena. English language edition” 19992000, no. 18 , pp. 38-57.

${ }^{10}$ B. Srbljanović, "Porodične priče," [in:] eadem, Pad - Beogradska trilogija - Porodične priče, Belgrade 2000. Theatrical premiere: "Atelje 212", 1998, dir. J. Marković.

${ }^{11}$ One of the best-known Serbian authors, cooperating with many European artists. Politically and socially involved lecturer at the Faculty of Dramatic Arts in Belgrade and a juror in prestigious playwriting festivals.

12 M. Lazin, “Otkud uspeh Biljane Srbljanović?," [in:] Dramski tekst danas..., p. 172. Quotation trans. by G. Abrasowicz. 
the needs of the game is trying to conform to the binding standards and even uses mute "dog's" language, is rejected and her "otherness" is met with rampant cruelty.

The children's dialogues are a perfect illustration of the claim that a child comes to this world as a "blank slate" and uncritically absorbs - like a sponge - verbal and non-verbal information. ${ }^{13}$ It is a re-creation of an adult world through children's eyes. The characters pretend the real and make their pretence obvious, their language being a parody of adult language and hate speech. The author shows a childhood caged and imprisoned in a series of quotations, rife with compulsive abuse, scenes of domestic violence and instances of bullying the weaker, discrimination on the basis of national origin, ethnicity, religion and gender, thereby referring to typical perversions of that time.

The play Maya and I and Maya ${ }^{14}$ (Maja i ja i Maja ${ }^{15}$, 2012), where Milan Marković $^{16}$ (1978, Belgrade) compiled his native and western-European artistic concepts, represents a slightly different convention. It is based on the motifs from the series of children's books Martine by Belgian authors Gilbert Delahaye and Marcel Marlier, very popular in former Yugoslavia, and a novel by Serbian writer Sreten Ugričić. The main character of this illustrated series first published in 1954 lived in Brussels and enjoyed a happy, enviable childhood. Her name was changed in the version published in Belgrade and Zagreb and as Maya she left a permanent and positive trace in the imagination of the generations growing up in the former Yugoslavia. Ugričićs book Maya and I and Maya. A Book on Growing Up (Roman o odrastanju, 1993) tells a story of the disintegration of Yugoslavia and political transformation in Europe from Maya's point of view and shows how they affect the girl's so-far carefree life. A brutal statement appears on the book's first pages:

Maya, who we all know, doesn't exist. Books with pictures lie. Real Maya lives in Brussels. Maya and her brother Miša are playing new games.

This introduces the change of mood and the novel's perspective. The reader has access to the biographical note of the Maya from Belgrade, who tries to find a connection between herself and the protagonist of the original series and says:

${ }^{13}$ V. Satir, Rodzina. Tu powstaje człowiek, trans. by Ł. Ochmańska, M. Trzebiatowska, Gdańsk 2000 , p. 56.

${ }^{14}$ M. Marković, Maya and I and Maya, trans. by M. Stojanović. The play is accessible in the public domain in an electronic version "Nova drama," https://docs.google.com/document/d/1LFtYf4rqtBlhRNGGZrGtPn1Rd86bB1MGK8TkQzM3GU/edit (access: 10.04.2017). The quotations come from this version of the text.

${ }^{15}$ M. Marković, Maja i ja i Maja. The play is accessible in an electronic version without pagination in the public domain "Nova drama," https://docs.google.com/document/d/1LFtYf4rqtBl-hRNGGZrGtPn1Rd86bB1MGK8TkQzM3GU/edit (access: 10.04.2017). Theatrical premiere: "Bitef Teatar", 2012, dir. A. Suša.

16 Coordinator of the "Nova drama" project in 2007-2010, for years involved in the broadly understood theatrical scene in Belgrade. At the same time he cooperated with Croatian, Slovenian, and Danish artists. At present he lives and works in Sweden. 
despite many differences, such as the fact that she and Maya certainly live in different places, that is Maya probably lives somewhere where litter is recycled, while she throws her litter into a common container, both show incredible life optimism.

The Serbian Maya is suspended between two worlds and between two orders - the voice of the past and the voice of the future. The book features fragments concerning the memories of childhood (descriptions of childhood illnesses and imaginings of possessed superpowers) and Yugonostalgic visions (a trip from Brussels to the Adriatic):

The trip was nice and we're happy that we've reached Yugoslavia. Yugoslavia is a beautiful country. It's a shame that it doesn't exist.

Serbia is beautiful, it's a shame that it doesn't exist.

Serbia is horrible, it's good that it doesn't exist.

In the play, a fable is confronted with the brutal reality and changes into a nightmare. The girl is tormented by the feeling of maladjustment, inability to grasp the rhythm of changes, and powerlessness. The atmosphere of hatred in which she grows up begins to block her:

faggots hate gypsies gypsies hate women women hate workers workers hate intellectuals intellectuals hate peasants peasants hate politicians politicians hate gypsies gypsies hate intellectuals intelectuals hate faggots faggots hate workers workers hate women women hate politicians politicians hate peasants peasants hate faggots faggots hate women women hate intellectuals intellectuals hate workers workers hate gypsies gypsies hate peasants peasants hate politicians politicians hate this city

Maya also experiences domestic violence and deprivation of her basic needs, which are interwoven with the chaos of war and transition, affecting the situation of an emotionally unstable child who - wanting to express the emotions exceeding her powers of understanding - resorts to antisocial behaviour and ultimately kills her parents. She is locked up in a youth detention centre and isolates herself from the brutal and inhospitable world that surrounds her by making sentimental journeys into the past and the safe fairy-tale world.

The Maya project comments on the post-Yugoslav heritage. The most painful motifs are seen here in the context of contemporary personal and social memories. Maya symbolises the lost generation whose hopes used to be so great. She embodies the common need of finding the culprit and demands compensation:

MAJA: sometimes it feels that this world is too big and then that it's too small when I close my eyes and press them tight with my hands I see rings of fire and then I want to set it on fire the whole world

to retaliate

for what

for everything

The Serbian "Everychild" at the end of the 20th century struggles with the problem of dealing with the open symbolic wounds and the unspeakable loss of stabilisation and perspectives. 


\section{Bosnia and Herzegovina: Troublesome childhood}

Tanja Šljivar consistently focuses on the communicative potential of the children growing up in adverse conditions in Bosnia after 2000. ${ }^{17}$ In her texts she draws attention to psychological and social processes which force children to modify their perception of the world, their knowledge and beliefs, interpretation of the past and the anticipation of the future, projects, and prejudices. ${ }^{18}$ Rather than arrive at them themselves, they adopt them as troublesome heritage. The protagonists of Tanja Šljivar's plays undergo significant transformations in quite limited spheres of life, which have prolonged, sometimes disastrous effects and exert a destructive influence on the children or, more specifically, on their views of the surrounding world.

Tanja Šljivar's ${ }^{19}$ (1988, Banja Luka) diploma work aims at describing the harsh post-war reality disrupting the process of growing up. The play Scratching, or: How My Grandmother Killed Herself20 (Grebanje ili Kako se ubila moja baka ${ }^{21}$, 2012) is set in 2000 in Banja Luka, before the hope that the future will bring prosperity and stabilisation died in the turbulent period of system reconstruction. We are also told about the events which take place later, in Frankfurt, when the protagonist, Maya, sells videos featuring her and her male friends. She tries to maintain her difficult friendship with the "Little German Girl who used to be Serbian..$^{22}$ The more experienced immigrant character gives Maya invaluable advice, teaches her the language and helps her to survive and assimilate in a foreign country.

${ }^{17}$ According to the author, a child character has a great performative potential, offering a wide range of interpretations for the audience and the actors. Her play We Are the Ones Our Parents Warned Us About (Mi smo oni na koje su nas roditelji upozoravali,2014) focuses on the fate of children confronted with the withdrawn representatives of the parents' generation. Representatives of two different generations meet in a public toilet and tell about their lives using the role-play technique. A teenager and a mature woman play the roles in archetypal configurations: mother-son, fatherdaughter, brother-sister, lovers. Their memories are triggered by random inscriptions on the tiles, the phrases which describe stages and episodes from their biographies: a mother bewailing the suicide death of her son, the date of the first menstruation, a message concerning the relationship between a brother and sister, a prostitute's advertisement. The tension between the protagonists prevents unrestricted articulation and communication; they feel uncomfortable and lost in the language, because the memories and experiences are manipulated.

18 J. Guichard, "Transition," [in:] Orientation et insertion professionnelle, ed. by J. Guichard, M. Huteau, Paris 2007, p. 432.

${ }^{19}$ Born in Bosnia and Herzegovina, the author is a graduate of the Faculty of Dramatic Arts in Belgrade. She cooperates with Serbian playwrights and stage producers. She continued her studies at the Justus-Liebig-Universität in Giessen.

${ }^{20}$ T. Šljivar, Scratching, or: How My Grandmother Killed Herself, trans. by K. Latinović. The play was made available to me in the electronic version by the author herself, for which I am grateful. The quotations come from this version of the text without pagination.

${ }^{21}$ T. Šljivar, "Grebanje ili Kako se ubila moja baka," [in:] Biseri iz upravničkih fioka, ed. by S. Bodroža, Belgrade 2013. Theatrical premiere: "BNP Zenica”, "Bitef”, "Hartefakt Fond”, 2012, dir. S. Spahić.

${ }^{22}$ A character in the play (text without pagination trans. by K. Latinović). 
Šljivar orchestrated the work about the acute experience of transformation into the voices of ten-year-olds, who are preparing a charity event in a school gym. They are not aware that gyms were used as torture chambers and temporary concentration camps during the war in Bosnia. The event is theoretically supposed to improve the quality of life of their disabled friend Kosta. The author veers away from the main plot to introduce bitter-sweet memories of growing up at the beginning of the new millennium, interweaving them with the scenes of the suicide of Maya's grandmother, the only adult the protagonist tolerates. She sees her grandmother as an idol because she lived an intensive life and was able to free herself from the yoke of the harsh reality.

Maya and her friends are deeply embedded in the "worse" culture of the wild and primitive Bosnia, dreaming of Western luxuries (sweets, games and toys, colourful clothes) and relishing their cheap imitations. With their consumerist attitude, they compensate for the lack of stability and security:

SLOBODANKA: For my next birthday, I will bring a whole carton of candies to school, I hope I'll find the spotted hyena by then. There will be chocolate prince and princess, and almond pralines, and gummy bears and mint bonbons and griottes and the chocolate ice-cubes. I will sit in the back and devour it, until I get sick. And after I vomit in the toilet, I will wash out my mouth with cool water, grin at the mirror and that's going to be the best birthday ever.

Maya gets a chance of a new, affluent, civilised life in the West. The girl reveals a secret that the school event is in reality a farewell party:

MAJA: Tonight I'll stare at billboards and my dad at a four-lane highway. Kicked back in the backseat, counting trees, I ask him if we're there yet. No we're not. Then I eat all of my snacks, drink some coke, are we there yet. No we're not. Then I strangle him and drive back. No we're not.

As a child she is not prepared for such a revolutionary change; she senses that moving amounts to more than just the change of address. Her friends envy her and fail to see the negative aspects of such a drastic change:

KOSTA: Maja, where is your dad taking you? Maja, Maja, where, where, where is he taking you? MAJA: To Germany.

ĐORĐE: So what, there's Bayern Munich and Bayer Leverkusen and Bayer's aspirin and you're good.

The protagonist is unable, and does not want to, part with her largely painful past. Maya believes in the memory of the body and provokes her friends into scaring and mutilating the skin of each other's bodies, combined with a semblance of sexual initiation. She believes that the wounds will enhance the collective memory, rooted in common personal experience and desires articulated in a convention of a symbolic language.

A Serbian playwright Filip Vujošević observed that this text "directly and brutally addresses the experience of pain and intensifying pathology among children 
manipulated by their parents, teachers and the nationalist environment in which they grew up". ${ }^{23}$ Even when playing children's games, the young protagonists are cruel and know no limits. The violence, resulting from unsatisfied desires, the absence of relationships with the parents, and the inability to express feelings evolves from the stage of scratching one's own and friends' bodies to shooting and sadistic bullying of the weaker. In this context Tanja Šljivar tells a story of departure and loss, of the generation who suffered growing up in the system devoid of real values replaced by prohibitions and orders.

In her latest work, All Adventurous Women $\mathrm{Do}^{24}$ (Kao i sve slobodne djevojke $e^{25}$, 2016), Śljivar also exposes the children's point of view. This time the stories of a group of girls make up a critical commentary on the disastrous level of sex education and the hypocritical morality in Bosnia and Herzegovina. Seven scenes and seven monologues by teenagers constitute the formal framework of the play based on real events publicised in the media which caused a nation-wide debate on the changes in the morals and shocking trends taking root among adolescent girls.

The subtitle, A play about a small-town attempt for big-world freedom, defines the setting in which a dramatic clash between the relish of progress and a parochial mindset eventually takes place; its victims are children whose needs are ignored. The protagonists, thirteen-year-olds who became pregnant during a school trip and were forced to undergo abortion, may have an unfounded sense of accomplishing a mission of creating a certain kind of liberal feature but they still behave childishly. They function in cyberspace and their knowledge of the world is based on bits and pieces of frequently distorted information on sexuality, sexually-transmitted diseases and contraception. Their rituals of rejecting childhood are more rapid and radical than typical maturation in the period of developmental transition.

\section{Montenegro: Childhood and the defence against the dictatorship of adults}

An individual functions in many contexts and is involved in various systems, trying to live up to many - often contradictory - expectations and requirements. Therefore, he or she regularly, even every day, moves from one form of activity to another. In Maja Todorovićs texts a regular transfer between various contexts of activity is disrupted. Transitions between the domains of life and situational trans-

${ }^{23}$ F. Vujošević, Riječ dramaturga, http://www.bnp.ba/bnp/predstave/velika-scena/grebanje (access: 20.03.2017). Quotation trans. by G. Abrasowicz.

${ }^{24}$ T. Šljivar, All Adventurous Women Do, trans. by Ž. Maksimović, C. Tamler. The play was made available to me in the electronic version by the author herself, for which I am grateful.

25 T. Šljivar, Kao i sve slobodne djevojke. The play was made available to me in the electronic version by the author herself, for which I am grateful. Theatrical premiere: Gradsko dramsko kazalište "Gavella", 2016, dir. A. Tomić. 
gressions ${ }^{26}$ turn out to be inadequate and fail to meet the children's expectations. Burdened with the problems of the adults, they develop defensive strategies and decide to escape into imaginary lands or hang on tightly to their dreams.

In Maja Todorović's ${ }^{27}$ (1990, Split) play Chinaman ${ }^{28}\left(\right.$ Kinez $\left.^{29}, 2013\right)$, a microstory about the birth of a friendship, hardships of cultivating it and parting, young protagonists learn to find sense in the labyrinth of prejudice and exclusion of the "others". The reflections on the (post-)transitional society are enriched by the introduction of the character of the eponymous Chinaman, who is:

(by years grown up, but by all the others a child) - no one knows where he came from. He is always there somewhere. He has slanted eyes; some would say that he is a Chinaman and some that he is a trisomic.

The play was recognised as the best dramatic text for a young audience by the organisation "Assitej" Montenegro. The author expressed very subtly the theme of painful and turbulent growth in the environment of the undermined system of values, where lost and lonely young people are engulfed by the virtual world of computer games and dysfunctional relationships.

The protagonists - two children who play with the Chinaman - live in the present embellished with the memories of tragic events, which cannot be erased from memory. They invent English-sounding names for themselves (Aleksa is Bren and Emilija is Amy), living in the rhythm of intensive and quick changes and taking over the drive for destruction from their parents:

BREN: Gonna shoot, gonna shoot, gonna burn, gonna burn like fireworks, fireworks. The whole world is going to burn. (...) It exists... Everywhere in the world. And here and there with my grandparents and with my dad's and there at the end of the world, there in, in... China. (...) And all of these people have agreed to make their bombs and bury them in the ground. And then, one day, when they all agree, but not all, they will press the button. But only if all of them agree, if anyone presses, sooner or later, or nothing, everything fails and everything must start again.

AMY: No, no, I'm asking you what do you want to go away all?

BREN: Just like that. The world is ugly and people are evil. It does not deserve to exist. It needs to be to destroyed and to create a new one, and better one. My mom said so.

${ }^{26}$ A. Bańka, Ocena, pomiar i usprawnianie jakości procesu doradztwa zawodowego, Warsaw 2005, p. 38 .

${ }^{27}$ A graduate from the Faculty of Dramatic Arts in Belgrade. Her plays premiered in the Beogradsko dramsko pozorište; now deeply involved in the Montenegrin theatrical world. Her work was appreciated by jurors of various festivals, directors and the audience.

${ }^{28} \mathrm{M}$. Todorović, Chinaman, trans. by J. Bang. The play was made available to me in the electronic version by the author herself, for which I am grateful. The quotations come from this version of the text without pagination.

${ }^{29} \mathrm{M}$. Todorović, Kinez. The play was made available to me in the electronic version by the author herself, for which I am grateful. Theatrical premiere: Kulturni centar "Nikola Đurković" - Kotor, Fondacija kotorski Festival pozorišta za djecu, Gradsko pozorište Podgorica, Međunarodni Festival Koto Art Teatar i Assitej centar Crna Gora, 2014, dir. A. Suša. 
Psychoanalysts have often discussed the emotional and symbolic importance of fairy tales for children. Bruno Bettelheim famously assumed that in the course of a natural, undisturbed development, children move onto another level of play and magical thinking, which helps them to control the reality. ${ }^{30}$ Brought up in difficult conditions, Bren and Amy are saved by the Chinaman. While playing with the strange and exotic man, they may at last escape into the alluring world of fantasy. The "magician", living at a Chinese market, curious and irrational in his behaviour, is a child in a body of an adult and their guide.

New dimensions created around the dilapidated housing estate enable the children to sever any links with the world of adults and escape from the imperative to grow up. Their games trigger alternative thinking, teach them how to plan and organise the future and how to develop social competences. The protagonists move between the tangible and imaginary worlds but become more involved emotionally in the latter, which only they are able to understand:

The marketplace as before. There are several packages and more bags brought by the wind. Chinaman, Bren and Amy are sitting around one large layout. The mock up is something like a small place, small town. There are small houses, roads, boats from Kinder eggs, brushwood, stones... Everything is neat and colorful, like a dollhouse that we used to made when we were little ones.

In this way they release anxiety and stress, forget the depressing news, violent arguments between adults and their political views.

Requiring a considerable amount of time to become a rationally thinking adult, a child resorts to various magic objects and characters to understand the world and abstract notions (such as evil, good, justice) and to attain a sense of security, which is also the case for the protagonists from Maja Todorovićs play. Their situation can be accounted for by Bettelheim's observation that premature rationality, frequently required from children by adults, similarly to other premature life experiences, is not only unnecessary but also detrimental. Small children are not yet ready for cognitive confrontation with real life. ${ }^{31}$

Maja Todorović explains in the introduction that "this is a story with the children, but not for the children. This is a story about us, a bit older children being afraid of growing up. As it is the same is painful. No one has told us how much".32 This statement fully conveys the atmosphere and meaning of the play: Even though the setting is "here and now", the atmosphere of the 1990s, the time when the author grew up, is distinctly present. Todorović confirms that the consequences of dramatic changes in economy, politics and morals are still felt today. Today's children, teenagers and young adults are in a sense a "product" of those changes. Therefore, the play's protagonists are undoubtedly the representatives of a new and modern gener-

${ }^{30}$ B. Bettelheim, The Uses of Enchantment. The Meaning and Importance of Fairy Tales, New York 1976, p. 57.

${ }^{31}$ Ibid.

${ }^{32}$ M. Todorović, Chinaman (text without pagination trans. by J. Bang). 
ation, but all the same they evoke nostalgic memories. The overwhelming problems which Bren and Amy struggle with - their mother's illness and death, emigration, financial problems, emotional deprivation - are by no means trivial and childish; they will probably become more acute in the process of their growing up and in adulthood.

Maja Todorovićs other play about growing up is My Daughter... ${ }^{33}$ (Šćeri mo$\left.j a . .{ }^{34}, 2015\right)$. By introducing the authentic characters of Ljubica Petrović-Njegoš of Montenegro and her family, this unconventional drama resorts to modern, critical, and slightly ironic language to tell a story of a patriarchal society and a woman's struggle for identity. The author explains that even though the characters are historical figures, their story is only a pretext for a reflection on contemporary issues, such as the status of women and girls. The play introduces the eponymous daughter, Zorka, and follows her life from the moment of birth (1864), through her childhood and growing up to her marriage with Peter Karađorđević, and death when giving birth to their fifth child (1890). The inquisitive Zorka, the king's oldest and favourite child, senses the need for change and reinterpretation, and asks questions which cause embarrassment and discomfort in adults. Zorka is convinced that, as the first-born child, she should be the successor to the throne. Despite the relocation to other geocultural spheres (receiving education in Russia) and onto a different level of proprieties and ritual, she firmly believes that she will become a ruler similar to the British queen and will make the country prosperous. However, her education and changes in her worldview are in conflict with the tradition of slavish emulation and obedience.

The play's title suggests the way a father addresses his daughter. It is significant that the king extraordinarily addresses Zorka as "my daughter" and not "my son".35 The ruler Nikola I Petrović-Njegoš is torn, because on the one hand he wants to support his daughter and her revolutionary ideas, but on the other he is an embodiment of stability and tradition. The representative of the exceptional group of "Daughters" struggles with various forms of pressure - from society and its moral, and the family. She was forced to undergo transition by quoting norms and in defiance to her internal rhythm she adopted the role imposed on her from above. As every individual, Zorka should move from one stage to another only after certain psychological phenomena take place. As every human being she had her own schedule ${ }^{36}$, but in her case the child grew up prematurely.

${ }^{33}$ M. Todorović, My daughter..., trans. by J. Bang. The play was made available to me in the electronic version by the author herself, for which I am grateful.

${ }^{34} \mathrm{M}$. Todorović, Šćeri moja... The play was made available to me in the electronic version by the author herself, for which I am grateful. Theatrical premiere: Crnogorsko narodno pozorište, 2016, dir. A. Vukotić.

35 Serbian and Montenegrin conservative families commonly address daughters as sons, which expresses a desire to have a son; the term "сине" functions as a colloquial phrase.

36 A. Brzezińska, Społeczna psychologia rozwoju, Warsaw 2000, p. 227. 


\section{Kosovo: Excluded childhood}

In the plays by Kosovan author Jeton Neziraj children are presented as the silent victims $s^{37}$ of social exclusion. Respect for a child's subjectivity and his or her rights is directly determined by a general attitude to individualism and human rights as well as the development of widely understood democracy. The children in Neziraj's plays experience transition between worlds, one of which they hardly know from direct experience. ${ }^{38}$ They are stigmatised and doomed to inadequacy, which prevents their social inclusion and further complicates the anticipated changes of status occurring in life, caused by growing up and acquiring new experiences.

Speckled Blue Eyes ${ }^{39}$ (Sytë e shkruar ${ }^{40}$, 2002) is Jeton Neziraj's ${ }^{41}$ (1977, Kaçanik) first play written directly for children. The Drama Workshop for children in Skopje (Macedonia) led by Swedish dramaturge Marie P. Hedenius and the knowledge that he acquired regarding dramaturgy and theatre for children in Sweden was the main motivation that pushed him to write children's plays. Since that time, he has written plays for children. Neziraj divulges that children's theatre in Kosovo continues to treat children as naive and stupid and as a playwright he wants to change that. ${ }^{42}$

The protagonists are Kosovan children who experience profound transformations, including those in the economic and social sphere. The play is interwoven with fragments of Luan's confession monologues and questions asked by his mother. Yet, it is his marginal and inaudible inner voice that informs the audience about his experiences and memories.

LUAN'S VOICE: Yesterday I heard a boy as he was saying to his friend that I do evil things because I have speckled blue eyes and he was also saying that... that my mother is a witch! What should I do mother, how should I protect myself from their words! [Silence] Once you told me that I have the most beautiful eyes in the world. Are the speckled blue eyes good or bad, mom? [Silence] The money that I brought today seemed too little to daddy... (p. 9)

A mute boy who does not verbalise his needs and does not communicate in a usual way is mysterious and suspicious. In the eyes of his peers his otherness be-

${ }^{37}$ Jeton Neziraj writes successful plays for young people, which also enjoy popularity with adult audiences as well; they have hidden meanings not always seen at first glance. Apart from the works discussed here, The Windmill and The Bridge, among others, deserve attention.

38 B. Rożnowski, Przechodzenie młodzieży z systemu edukacji na rynek pracy: Analiza kluczowych pojęć dotyczacych rynku pracy u młodzieży, Lublin 2009, p. 13.

39 J. Neziraj, Speckled Blue Eyes, trans. by F. Bajraj, Pristina 2009. Further quotations with page numbers come from this version of the text.

${ }^{40} \mathrm{~J}$. Neziraj, Sytë e shkruar. The play was made available to me in the electronic version by the author himself, for which I am grateful. Theatrical premiere: "Albanian Drama Theatre" (Skopje, Macedonia), 2005.

${ }^{41}$ Neziraj's plays have been performed in many important theatre festivals in Europe. He was the Artistic Director of the National Theatre of Kosovo and now he is the Director of Qendra Multimedia, a cultural production company based in Pristina.

42 J. Neziraj, Interview: playwright Jeton Neziraj of Kosovo, http://writelocalplayglobal.org/articlesinterviews-database/2011/8/8/interview-playwright-jeton-neziraj-of-kosovo.html (access: 04.07.2017).

Miscellanea Posttotalitariana Wratislaviensia 7, 2017

(C) for this edition by CNS 
comes a great deficiency. Everything that concerns him — his appearance, behaviour, family situation - causes their anxiety.

GENT: Have you seen his eyes, he has speckled blue eyes. My granddad once told me that all those that have such eyes do evil things. (...) Do you know that whoever is weighed in his scale won't have luck in his life? Seems nothing to you? Don't you know that the speckled blue eye does many evil things? Everybody knows it. (p. 35)

Luan never went to school, because just before it started he had experienced a great trauma which prevented him from receiving a traditional education. He is hungry for knowledge and has artistic talents. His drawings are unsettling and at the same time fascinating. It turns out that a mysterious woman from his drawings is his mother, who committed suicide and who is still his spiritual guardian. Now he is looked after by his father - an alcoholic veteran - who hardly manages to fulfil this role. Disabled by pain caused by war wounds and psychologically broken, he expects Luan to help him run the household. The boy is expected to earn money weighing people in the street, and the portable weighing scale becomes his attribute. The growing-up protagonist is burdened with too many negative stimuli and expectations, which he cannot bear and therefore he remains in the background, observing changes taking place around him while he remains suspended in the transition zone.

The only kind person who tries to make friends with the boy is Drita. She communicates with him and teaches him the alphabet and all the basic knowledge. She also tells him about the better, Western, world and the opportunities it offers. The most attractive are sweets, toys, and a magnetic board with letters, unavailable in Kosovo. The girl functions at a completely different level - she lives in a complete family even though she suffers because of the absence of her father, a gastarbeiter. Thanks to the fact that her father works in Germany, her family's status is much better and there is also a prospect of emigrating and leaving Kosovo forever, which is what Drita's mother wants, describing life in Pristina as unbearable in the conversations with her husband on the telephone:

SPHRESA: I cannot cook anything because we don't have electricity... Almost for three hours we don't have electricity... But he doesn't eat anything, he's still in the intensive-care unit... Yes, we have water... You are not believing me, you think that I'd like to come there just for fun... It's impossible to live here... Call anytime you want... Last night I couldn't sleep at all... Even tonight I might not sleep... (pp. 54-55)

At some stage critical events accumulate: one of the boys is brutally beaten, Drita and Burim's father returns from Germany and Luan's father finds out that he does not qualify for an operation that was supposed to ease his pain. A dramatic scene when the boy's father attempts suicide causes a shock and unblocks Luan. He begins to talk and is ready to begin the normal process of growing up.

LUAN: [Off] "L", yes, this is "L"... "O", this one I remember... "V" as a vehicle... And in the end "E" as an egg... That's it. (p. 72) 
The ritual of transformation experienced by a child during a developmental transition in adverse conditions involves the sense of being uprooted and incomprehension, especially when the subject is in a state escaping unambiguous definition, requiring assistance in the process of natural development and acquiring competences to construct his or her own life and a sense of self.

The author emphasises the fact that exclusion in childhood is especially dangerous because it constitutes a barrier in the individual development of a person and restricts the use of one's potential in the future. The protagonist of Nezirajs another play, Yue Madeleine $Y u e^{43}$ (2012), a Romani girl who came to the Balkans from the West, is a symbol of intense exclusion and alienation. This tragicomedy tells the story of a Roma family that was forcedly expelled from Germany to Kosovo. In their new reality, this family confronts the challenges of living in a recently newborn state. A Roma girl named Madeleine after diplomat Madeleine Albright learns the differences between the prosperous world of clear-cut rules and Balkan chaos. Wanting to blend in with the new reality, to adjust and function independently, she decides to come home from school on her own. She falls into a hole on the road, left unsecured with safety barriers and unmarked by the workers, who treat it as a grave. The girl falls in a coma. As she fights for her life, her father strives to pursue justice. He faces bureaucratic officers, businessmen, policemen, and embassy workers.

Even though a new country is indeed developing, the pace and consequences of the development are disappointing. The police do not take the accident seriously and blame the girl's parents, accusing them of the inability to adjust to the conditions of life in Kosovo and of ingratitude to the authorities. The real culprits do not consider their negligence as a mistake deserving punishment and do not feel responsible. Due to corruption, ignorance, and lack of money, the girl dies while her family are left with the feeling of injustice and rejection. Despite intensive discourse on various issues concerning social inequalities, it seems that the subjects of social discrimination and social exclusion of children are ignored. A "child" is often associated with a weaker, imperfect version of an adult. During the process of growing up Madeleine needed guardians who would bring her up and explain how to live. At the same time, she should have been protected against the culture of adults to enable her to maintain childlike innocence, security, and life.

43 J. Neziraj, Yue Madeleine Yue, trans. by A. Hoppe, [in:] eadem, Six Plays, Pristina 2014. The play was originally written for the Volkstheater in Vienna, Austria, dir. B. Neziraj. The author explains that the first version of this play was staged in Pristina in 2007 with the title The Town is Expanding. The second edited version was published as Madeleine's War. As Neziraj planned to re-write the play, he was shocked by a video on the Internet. It showed a young Chinese girl named Yue Yue, who was hit by a truck and left alone bleeding on the street. She died after a few days in a coma. The author emphasizes the connection between Yue Yue and Madeleine. 


\section{Conclusions}

Variously understood transition left its imprint on the subject matter and aesthetics of contemporary playwriting in the countries that emerged following the disintegration of Yugoslavia. The young protagonists of the dramatic texts presented above experience diverse transitions as difficult situations, resulting from the lack of equilibrium between the needs and tasks on the one hand and the ways and conditions of their accomplishment on the other. Each transition requires mobilisation, learning reflective de- and (re)construction of biographies, and acquiring skills of constructing many life scenarios (even though none guarantees success and happiness), which in turn enables adaptation to various environments. This task is especially difficult for children who encounter permanent and accumulating change.

The presented works also touch upon the theme of a difficult road to stability and consolidation ${ }^{44}$, (de)construction of systems and the related side effects. The attitude of the authors from Serbia, Bosnia and Herzegovina, Montenegro and Kosovo discussed here to economic, political and national transitions is at least ambiguous. The specific micro-group of children - protagonists of the dramatic works - suffer the greatest consequences of the transition between civilisational orders, which in turn affects their developmental transitions, because the problems resulting from the change in the system of power and the existing adverse conditions disrupt their development. The children are coerced into premature pseudo-maturity or symbolic escape and isolation.

The authors also reflect on the problem of experiencing pain which appears when a person contemplates his or her life, analyses the order of things in the surrounding world, plans the aims in life and strives to discover its sense, and when the lack of control over transfers and inability to attain identity equilibrium in the interaction with others become distinctly visible. The dramatists transfer this struggle onto the children protagonists. It is children, attentive observers of the emerging framework for the functioning of the new system and its involuntary users, that diagnose - like litmus paper - all social dysfunctions. The picture of the young generation, a reflection of today's adults, enhances the tragic message of the works and imparts a new dimension to the socially committed theatre, which "causes a reaction and calls for assuming responsibility". ${ }^{4}$

${ }^{44}$ Seen through the lens of political science, Serbia and Montenegro have made a turn towards democracy and have partly consolidated it, Bosnia and Herzegovina remains in the state of destabilisation under an interim regime, while Kosovo represents a partially consolidated authoritarianism. A. Antoszewski, "Wyboista droga ku demokracji i autorytaryzmowi w świecie pokomunistycznym," Wrocławskie Studia Politologiczne 2014, no. 16, pp. 7-23.

45 T. Šljivar, “Mi smo oni na koje su nas roditelji upozoravali. Intervju," Vreme 30 May 2013, http:// www.vreme.co.rs/cms/view.php?id=1117255 (access: 20.01.2017). Quotation trans. by G. Abrasowicz. 


\section{Bibliography}

Antoszewski, Andrzej. 2014. "Wyboista droga ku demokracji i autorytaryzmowi w świecie pokomunistycznym.” Wrocławskie Studia Politologiczne 16: 7-23.

Bańka, Augustyn. 2005. Ocena, pomiar i usprawnianie jakości procesu doradztwa zawodowego. Warsaw: Ministerstwo Pracy i Polityki Społecznej.

Bańka, Augustyn. 2006. Poradnictwo transnacjonalne. Cele i metody międzykulturowego doradztwa karier. Warsaw: Ministerstwo Pracy i Polityki Społecznej.

Bettelheim, Bruno. 1976. The Uses of Enchantment. The Meaning and Importance of Fairy Tales. New York: Vintage Books.

Brzezińska, Anna. 2000. Społeczna psychologia rozwoju. Warsaw: Scholar.

Drabik-Podgórna, Violetta. 2010. "Tranzycja jako nowa kategoria biograficzna we współczesnym poradnictwie zawodowym." Edukacja Dorostych 1: 91-104.

Giddens, Anthony. 2000. Nowoczesność i tożsamość. "Ja" i społeczeństwo w epoce późnej nowoczesności. Translated by Alina Szulżycka, Warsaw: Wydawnictwo Naukowe PWN.

Guichard, Jean. 2017. "Transition." In Orientation et insertion professionnelle, edited by Jean Guichard and Michel Huteau. Paris: Dunod.

Lazin, Miloš. 2004. "Otkud uspeh Biljane Srbljanović?" In Dramski tekst danas u Bosni i Hercegovini, Hrvatskoj i Srbiji i Crnoj Gori, edited by Sava Anđelković, Novi Sad: Sterijino pozorje.

Marković, Milan. 2012. Maja i ja i Maja, https://docs.google.com/document/d/1LFtYf4rqtBlhRNGGZrGtPn1Rd86bB1MGK8TkQzM3GU/edit (access: 10.10.2017).

Marković, Milan. 2012. Maya and I and Maya. Translated by Marija Stojanović, https://docs.google.com/document/d/1LFtYf4rqtBl-hRNGGZrGtPn1Rd86bB1MGK8TkQzM3GU/edit (access: 10.10 .2017$)$.

Neziraj, Jeton. 2009. Speckled Blue Eyes. Translated by Fadil Bajraj. Pristina: Qendra Multimedia.

Neziraj, Jeton. 2009. Sytë e shkruar. The play was made available in the electronic version by the author himself.

Neziraj, Jeton. 2014. "Yue Madeleine Yue." Translated by Ajkuna Hoppe. In Jeton Neziraj Six Plays. Pristina: Qendra Multimedia.

Rożnowski, Bohdan. 2009. Przechodzenie młodzieży z systemu edukacji na rynek pracy: Analiza kluczowych pojęć dotyczacych rynku pracy u młodzieży. Lublin: Wydawnictwo KUL.

Satir, Virginia. 2000. Rodzina. Tu powstaje człowiek. Translated by Łucja Ochmańska and Małgorzata Trzebiatowska. Gdańsk: GWP.

Schlossberg, Nancy and Waters, Elinor B., Goodman, Jane. 1995. Counseling Adults in Transitions Linking Practice with Theory. New York: Springer.

Srbljanović, Biljana. 1999-2000. “Family Stories.” Translated by Vida Janković, Scena. English language edition 18: 38-57.

Srbljanović, Biljana. 2000. "Porodične priče." In Biljana Srbljanović, Pad - Beogradska trilogija - Porodične priče, Belgrade: Otkrovenje.

Šljivar, Tanja. 2012. "Grebanje ili Kako se ubila moja baka." In Biseri iz upravničkih fioka, edited by Stevan Bodroža. Belgrade: Ustanova kulture "Parobrod".

Šljivar, Tanja. 2012. Scratching, or: How My Grandmother Killed Herself. Translated by Ksenija Latinović. The play was made available in the electronic version by the author herself.

Šljivar, Tanja. 2013. "Mi smo oni na koje su nas roditelji upozoravali. Intervju." Vreme 30 May 2013, http://www.vreme.co.rs/cms/view.php?id=1117255 (access: 20.01.2017).

Šljivar, Tanja. 2016. All Adventurous Women Do. Translated by Željko Maksimović and Cory Tamler. The play was made available in the electronic version by the author herself.

Šljivar, Tanja. 2016. Kao i sve slobodne djevojke. The play was made available in the electronic version by the author herself. 
Todorović, Maja. 2013. Chinaman. Translated by Jasminka Bang. The play was made available in the electronic version by the author herself.

Todorović, Maja. 2013. Kinez. The play was made available in the electronic version by the author herself.

Todorović, Maja. 2015. My daughter..., Translated by Jasminka Bang. The play was made available in the electronic version by the author herself.

Todorović, Maja. 2015. Śćeri moja... The play was made available in the electronic version by the author herself.

Vojvodić, Radmila. 2004. "Politički angažman, organska mučnina i sentimentalizam beznađa." In Dramski tekst danas u Bosni i Hercegovini, Hrvatskoj i Srbiji i Crnoj Gori, edited by Sava Anđelković, Novi Sad: Sterijino pozorje.

Vujošević, Filip. 2013. Riječ dramaturga, http://www.bnp.ba/bnp/predstave/velika-scena/grebanje (access: 20.03.2017).

Accepted for publication: 15.09.2017 